\title{
Transferring of Limited Rights Model (TLRM) with the highest priority in the Theory of Development Plans
}

\author{
Aziz Cumhur KOCALAR
}

\author{
Assist. Prof. Dr., (Ph.D., M.Sc., B.Sc., B.A.); Cumhuriyet Universtiy, Faculty of Architecture, Department of City and \\ Regional Planning, Sivas, Turkey
}

*Corresponding author's Email: ackocalar@gmail.com, http://azizcumhurkocalar.blogspot.com/

\begin{abstract}
In this study, transferring of limited rights model (TLRM) is proposed as an innovative implementation instrument for development plans in which its coverage area with theoretical and practical approaches is a holistic structure in relation with different disciplines and so widely. The model can be used with protected areas easily or together with preventive steps in related to the emergency situations such as the natural disasters. This model is also kept its validation in cultural, historical, urban, archeological, social and natural assets, and also cost, forest, meadow, sheep, thicket, heath and national parks, at the same time protects quag, underground, surface water, dams, drainage or water basins besides disasters, forest fire, flood, avalanche, disasters at first or later. The proposed model can be utilized for the aim of public service, order and interest in the development planning studies and applications, in the urban conservation, renewal and regeneration, in the real estate's utilization of individual and corporate ownership, in the process of making laws, the regulations and the decisions since 1980, as a result of the planning qualified as a rule of transaction.
\end{abstract}

Keywords: Development plans implementation instrument, Transfer property and development rights, Transfer rights in the restricted immovable, Abstract and concrete allowances, Local authorities, TLRM, Property owner without land shares.

\section{INTRODUCTION}

Within the framework of changing and socialeconomic conditions, the strategic assumptions of the state to be known and re-designed are needed according to the objectives of contemporary in our country and the world.

All has required that solving problems; monitoring, transparency, supervision and evaluation by enabling qualities, increase accountability and predictability in the planning.

All solutions expected by society should have been in the macro-level objectives by line with these solutions related to which the planning can be realized in the following conditions:

The development plans could have been created by transformations in the society and in the economic, social and cultural fields. Besides the development plans should be privileged in the form of equal and fair practices, the processing with the coordination of the national development plans and the regional plans.

After 1980, in the Constitution, as stated in Article 166, the procedures and principles which were related with the details of the arrangement in general have left to the law. Also, economic, social and cultural development task of providing with plan has given to the government. Growing Plan from 2007-2009 during the following 7 years are given.

- Stability in the growth, more equitable revenue sharing,

Global competitiveness of ownership,

Transformation into an information society, - Provision of community contribution and ownership,
- Ecological and cultural assets protection with the environment,

- During the presentation of public services, transparency, accountability, participation, attention,

- Applications are based on human-oriented services, - Development Plans taking into account the zoning of property rights, equal and fair evaluation of pattern, - Urban Planning theories, to be included in the transfer of rights,

- Separation of the relevant areas as a priority, - Country, region, and the integrity of the policy complied with the protection of natural and cultural assets.

The regional planning task of the State Planning Organization (SPO) is given in auditable manner with certain provisions. Besides the Ministry of Public Works and Settlement should carry out an effective co-ordination across the country. The taking place with the returns (annuities) during urbanization must be solved since the benefit of the public and the community.

The development plans integrate decisions on the only legal document as an administrative regulatory process. But these are restricted on the rights of property and development in order to protect the culture and the community life. For this reason, the provisions of the rights might be separated of the fields.

The urbanization in the development plan applications must be waited for the creation of those life conditions: Healthy, equality, justice with the participation of rights owners and people in the region. At the same time, urban and environmental values and the protecting 
of the individual restricted rights should be observed strongly.

The expropriation as the implementation of onesided win is not unique solution and it must be owner. Before it, all the provision of restricted (lost) rights must define completely. And for this provision that belong to place, parcel, plot definitions from the reserve areas for the transfer rights should based of the development plan applications. The new application facilities should be provided for zoning policy in this way.

\section{The Development Plan Application Tools}

The Constitution gave the task of the conservation and taking the necessary measures to the government in the following areas:

It is ensured with the conservation of the history, the culture and the ecological environment assets, and also in the coastal, the forest, the pasture, the grassland, the marine, the die, the streams, the ground water and the surface water catchments [1].

- The state fulfills the duties of the conservation in the principle of the law, [2] based on the scope and the methods in the specified context.

- Well as the layout in this context identify those issues that must be made by the State Planning Organization (SPO), the socio-economic development, the purposes of settlement and industrial issues.

- The development plans, which will be made both inside and outside the municipality and contiguous areas in accordance with the regional plans, carried out stage in the Local Government [3].

- The areas in our country and the constructions in the locations of settlement should establish in the appropriate science of the health, the environmental conditions and also depending on the development plans, the regional conditions and the legislation comments [4].

Here is, this planning task of state for the entirely conservation aim to the environmental and the ecological systems with the historical, the cultural and the natural assets is the highest constitutional norms. But also with these regulations that created during these planning tasks are brought to life limitations.

The development plan application tools have been used so far in our country respectively:

-Expropriation,

- Change (exchange, clearing, barter, replacement, transfer),

- Transfer.

The expropriation, as required by the public interest, the property is to the public via paying the actual provisions of immovable,

In the change case, the corresponding price to the real estate in which the payment is expressed particularly.

If the case is the transfer, the immovable property in return for another is aimed. It is used as an alternative together with the expropriation [5].

\section{The Covering Transfer of Limited Rights in the Development Plan Theory \\ Ownership of real estate in our country is} considered as the most important individual savings. For this, all of options followed are synonymous: restrictive or annuity provider provisions in the ownership of real estate which are brought with the physical planning decisions; confiscation or; paying with cash into the bank savings account.

The rights vested with the construction of the development plan should be not abated. In addition, the property owners who are gains arising with this plan should be provided equal benefit and be made equal sacrifices. Although it is not mandatory, the planner should be aware of the ownership pattern of the real estate providing necessary options in above for this work. Because this annuity or victim hood with the ownership is provided with plan, the legal regulation for relief in this situation should be discussed to find [6].

Sometimes solving contradictions are difficult. Notwithstanding that the sensitivities of the city planner on subject of immovable property rights, those opinions showing a different angle for subject are also important in following: With this different angle, it can be focused on related legal arrangements to be done to correct the deficiencies in legislation and occupational qualifications.

"As a profession, the urban and regional planning recognizes cities especially in according to certain factors, or settlements in a general approach, and reads them. From geographical position, also according to social, cultural, economic, public space to analyze them, assessments, and results with interpretations is reached. Cities' planning is a decision system that detects problems in each venue in line with the evaluation, reviews and results. One planner must be much knowledgeable in areas such as sociology, law, economics, and architecture."

The subject of transfer action is a pattern of rights. If recognition is the foundation of the cities, since people knew it as a right buying their real estates, they have accepted these objects in their lives, whereat they must be read better [7].

In the city and regional planning, especially the life conditions of individuals and their environments as society there, the patterns of ownership should be determined as very sensitive.

In addition, after a good reading of the rights recognized with social expectations and means of interpreting, to be provided solution for problems at a good balancing point for the public interest, in this way, transfer of rights will be trouble free and the foundation of a healthy.

Starting with real estate property rights, including in building-development rights, ruminate on harmony and balance to providing around judicial system with the legal rights of individuals, shortly, tangible and intangible assets created by society's values. But with Cultural and Natural Heritage Protection Law can be realized in conservation via interpreting with the principles, rules and resources.

There is a conflict between protecting of public profit about public services in public space and the subject of the private ownership areas. The development legislation rules can prevent this conflict of private profits came from property.

\subsection{The Limited Rights in the Development} Plans

The conservation planning, limited ownership, development (zoning), urban and environmental rights by definition, framework and scope must be specified. 
It is the most important privilege being limitation between other real estate rights with the lost real estate rights under the conservation that restricts. The real estate potential rights in general meaning also cover these lost rights.

On the other hand, the physical environment with land, buildings, facilities, equipment and all attachments that are based on these rights are being protected together. This is another important difference.

During the conservation process, the immovable properties belonging to private individuals have been restricted by authority and in addition, the scope of real estate record description is also included the land, plants and resources with the supply layers in above or below.

In addition, the restricted rights are not only property rights, but also development, reconstruction, urban, environment, life and human rights are included.

The immovable property for protection of rights is being limited in two ways:

Being limited the property owner to be completely precise, in other words transfer to government.

The partial restriction over the property is another provision. In these circumstances, the property will have been remained on the property owner. At the same time, since development rights has accepted again, it will have been given in different place or with the different possible options [8].

\subsubsection{The Immovable Property Rights}

The definition of property on laws has not been exactly performed. But it has been emphasized with its scope and content, types, effects, privileges and restrictions. There isn't any full description in the laws, but its framework, content and types, affects, exceptions and limitations are defined.

Real property and land registry possession issues are processed on the Turkish Civil Law (TCL) [9]. The immovable property is shown on the legal register of land in the form in the registered rights of independent and continuous.

The definition of the right to immovable property can be made as follows:

- The right to property is belonging to individuals or legal entities, and is observed in their relations with the other individuals, groups, community and government.

- It is separate from the owner's own idea and selfexistence, but the owner can holds it as the property of her own, in the form of an agreement or the contract based on something, which is managed with the rules and defined in privileges.

- This right gives to owner some authorities like that use, saving, protection and consumption etc. It can be separated from the human right. At the same time, that is a vital element of existence for individuals but is not indispensable.

- The immovable property consists with the registration of the title deed and land office records. The state is responsible for keeping the register that is guaranteed. This is the official record that is constituted evidence of the accuracy of the cases in the documents [10].

- The independent and the permanent rights are used in conjunction with parcel and land ownership and the independent sections are subject of all immovable property. Both of them, which are the independent and the permanent rights with the independent sections about the condominium subject record to the land title registry [11].

The plan shall prevail on the land registry records and can be put an annotation onto the title deed with an owner request as follows:

- The construction for the share of land (flat received for land ownership), promise to sell, lease, purchase, preemption, repurchase rights, etc. rights with the accessories and the add-ons.

- All of those records are attributed to parties after being put an annotation onto the title deed, with annotations, recordings, and statements of the deed [12].

- The limitations with the public legislation depend on special law. They are valid without registration and also no changed and removed.

Those tables attached for real estate ownership cover many different attributes:

Sometimes lots which is seen as a land in the title deed registries, and then qualified and fixed as a piece of land or as a building with the class corrections. (16 types of immovable property, 16 types of property rights of building and 10 pieces of their qualifications are shoved by three different tables in the attachments.) [13].

\subsubsection{The Building-Development Rights}

Reconstruction to provide a place for and develop the layout of the building, the beautification, the optimization in the living conditions, the improvement and the flourishing etc. Shortly, it is realized for performing and optimizing the business of covering the whole of an organized system of architecture [14].

"Zoning laws in

many western countries and institutions of higher education is taught as a separate subject in vocational schools" [15]. However in Turkey, the name of a law takes "zoning" term (Zoning-Development law) and the word that is "iskan" are attached to the housing which is a Turkish name for the Ministry of Public Works and Settlement.

During development right is usually used instead of the concept, its framework or in scope is little wider. As follows; it is used when it is necessary to show a holistic architectural diversity in the borders of a particular place together with the scale of space structure, equipment, the plug-ins and environmental schemes.

According

to this explanation development rights can be defined as follows:

- The development plans are being definite made by the conditions of laws.

- It is used with made and approved projects practically as granted in the status of zoning in accordance with final plans.

- The development rights, that is expressing to be carried out the work the land organization in the form of their additional elements, facilities and environment schemes together with in all the constructions of landscaping.

- Since of these reasons, representing the entire field by a technical architectural integrity competence is called as development rights [13].

All elements of development (reconstruction) are expressing with this method that is: 
"Firstly, a particular area, location (land, parcel, area, etc.) are involved and then, the overall rate of all construction works, buildings, together with additional elements of the architecture and landscaping to form a unity in the form of making and flourishing." [16].

The right of building that is in the settlements as the owner of land, the plot or area according to the development laws, in accordance with the appropriate projects in the location which are given by zoning situation with the development plans. The right to represent the structure or the construction rights has been defined and used in the law in the form of "the Building Rights" or "the Right to Build" " [8].

In a certain area, after the development application project work is completed on the basis of island and parcel, building rights is realized. In the way of building method, with the development plans, the buildings to be done with all these principles are specified technically here:

- In which the plots, how, how much, which is the border, height, volume and area, and in what way.

- Since this right of the owner or property owners who want to use,

- To be made of construction, must be obtained licenses in legally.

They want to do the building, because of building conformity is accepted for adopting for all structural rules, together with projects and other documents, they would apply for the municipal directorate of the zoning.

The legal documents for basis of the building right, the development plan and the zoning certificate are given by the basis of plan. The development status certificate is a document that is showing with technical descriptions of building right on the lands [17].

However added to 17 items of the law (No. 2863), for a right widely will express a provision in following that has been canceled by The Supreme Court: "A sentence added into the law with the regulation, it covers different and dangerous content such as the creation of a team of some vested rights that are not in anywhere around the laws."

But the limits that, there are two different types of situations according to whether the ban is the partially or final in the building restriction, so that it have also been reported in various prohibitions apply for depending on situations.

The Precise Building Restriction (full limitation): Places where are declared in the area protected areas, if the ongoing structures is the appropriate for zoning laws and those level socle completed, precise restructuring of those banned from the site property and development rights are completely transferred to the field.

Even if these rights return in the 2nd area (Transfer Domain) old transfer rights has also been transferred, so they are completely restricted in the 1 st field. The immovable properties which are limited with precise structuring ban and the rights transferred on to there, along with plug-and complementary elements become the property of the administration and they shouldn't also sold under any circumstances.

\section{The Partly Building Restriction (partly limitation):}

However, if owner's right that is protected by construction in the transfer of property subject parcel, in the event that the right of the building is transferred into the 2nd area partly, the ownership in the remaining local area will continue.

In this case, it is not a complete restriction; there is the exception of the remaining buildings and places. But the limited section of the right of the building that has not used yet and also related with the 1st area, can be mentioned to transfer.

In the assets that are protected by laws, the transfer of property and building rights will be continued as long as the assets are protected according to the restrictions in the legislation.

In the event that if it is possible, these rights of the building are transferred into the 2 nd areas partly during another section of rights that is related to the property directly will be kept into the 1st (old) area protected. These rights that is transferred can be used in only the 2nd areas, but also not be able to used to the 1st area again or anywhere [18].

\subsection{The Transfer of Limited Rights with the Development Plans [19] \\ The public administrations prevent historical,} cultural and natural assets, national park, conservation (protected) areas, historical sites, coastal, forest, marine, lake, river, surface and under ground waters and lands, the air and the environment. Also Bosporus, industry, technological development, tourism encouragement, private environment protection regions on the basis of public interest, service, duty reasons.

Besides the conservation legislation included with local authorities in the last year are presented by an announcement in a conference that is named of IPHS in the last year [19]. Because authorities and local government bodies are authorized for transfers under section regulated by the Law. (Law No. 2863, amended as Law No. 5226/14.7.2004, No.17 article, cth paragraph).

"Transfer is not only for single-transaction owners in a -building land, but a contemporary tool which shall use principles and criteria actually providing a balance between the public interest and individual and corporate ownership."

Transfer Development Rights (TDR) is a contemporary tool to be lost rights and for balancing between the public and private ownership. So that, the authorization to be given them and how it is used in the last 6 years is also very important.

These rights said in above are coherent within the immovable rights. The provisions of these rights are provided by the different options in the form of making with the contemporary development plan tools such as exchange, replacement, exchange, transfer, exchange, and instead of giving, or expropriation in different countries.

Expropriation in Turkey, that provisions is interesting in the Expropriation Law (The Expropriation Law, Article No. 8, 26) that has also been added as a "purchase procedure" to compensation aimed in agreement with the partners and also "barter" concepts in times.

But also these regulations did not affect the use of expropriation. The Expropriation is practical way that is created and preferred by the public management and applied to one side is not enough in many approaches. 
These development plan tools have been applied until 2004 but with them, real estate price of private ownership could not go beyond with money or land as reserves.

Into the law, the concept of transfer is introduced with the related law added in 2004, its framework researched with many details by the dissertation work [8].

Now, this research improved with practical and innovative solutions for too many new problems about many conservation subjects and not only conservation but also in the urban regeneration projects, are updated by new framework of TLRM (BTM is riched) with the utilities of the each proposed sub-model again like as by the framework of BTM in the dissertation work.

So that these new areas for potential building rights of lost in conservation or other possible actions such as the urban regeneration and the urban renewal etc. should be created by the authorities or the governments continuously.

\subsubsection{The Description for Transfer of Property}

\section{\& Development Rights}

"Transfer is to be used instead of problem creating and outdated character of binding expropriation, which is an instrument of building plan implementation based on sanctions and one-sided.

Transfer is a right that requires participation of all parties by taking responsibility and authorization. It is a right that creates rules through a legal-administrative concept and action and it is supposed to provide solution of problems.

Transfer in implementation of building plans, stems from the necessity for utilization of unilaterally limited property and building rights for public interest and for public service in other areas." [19].

The broad definition is related to transfer includes all the protection of environmental values but where more, transfer will be discussed with according to the expression and the functions in the law with the boundaries which will remain within the scope of the research. According to this definition of transfer:

- Transfer is an applicable instrument with two phase to conservation aimed firstly in the immovable cultural and natural properties and areas where named by in the 1 st area.

- This tool can be used for the restricted section of the immovable property and development-building rights.

- These rights mentioned above to their owners have qualitative and quantitative values to be provided with the quality of life functions continuously, so that the rights should be evaluated with these types of details.

- There is exception for only antiquity, rarity and of the registered immovable cultural assets. And to be continued to ownership's structures and land values due to the partial rebuilding in the registered immovable.

- After evaluated if necessary, securitization is made.

- And the final stage is Transfer sub-model and is started to last processes in the 2nd area. These areas of transfer are open areas for building with the development plans.

- For transferring of the unique structure and the independent immovable of Cultural and Natural Heritage, in more different options can be created with in the immovable of 3rd people ownership where appropriate possibilities with the plots and the island are.

The holistic description of the necessary operations for transferring in this last process can be summarized basically as follows.

Operations where rightful owners' plans and projects prepared based on value of immovable and in accordance with their desires and cadastral extracts, are assessed according to the quality of building class.

Then, after matching and (-/+) equalization of those they leave in the Sending Area. Those will be given in the Receiving Area. The simultaneous and mutual handover procedures of individual monuments are conducted based on the approvals of both sides in the Transfer Incorporated Entity (TIE) when building and development processes are completed.

\subsubsection{The Transfer (2nd) Areas}

Here's a planner, although the property and development rights which are restricted for the plan applications of public. Whereas the provisions about them do not or no granted yet. It must be allocated for the fields to be transferred (2nd areas) firstly for these rights. Then, this policy should be separated on the basis of the purposes and methods.

Local governments should complete and approve the conservation development plans which is also mandatory with high priority as the first step towards transfer or rights for twenty-one 21 years between 1983 and 2004. It was introduced with law added in 2004 year. (Law Date/No. 2863/5226)

Hence, after 21 years, the 3-year 7-month period has been given by law for it again but it has also been expired at 14.2.2008.

"For the some open space areas devoted to transfer the property and development rights by urban development plans, in the municipality or thirdparty property ownership. The municipalities are authorized if they are in the municipal boundaries except for called governorates for these areas." [20].

Follows the setting principles about the 2nd areas;

- These 2 nd areas that are named transfer domains must be devoted to transfer as the open space with the development plan and the commentary on this issue must be also written off the title record of areas in deed.

- Besides ownership in there will be owned by the municipality or third-party areas.

- The appropriate fields of 3rd party' ownership are meaning that can be expropriation to be performed for the transfer service.

- Transfer in law with these issues is counting as a 'public service', for fulfillment, if no any appropriate field, being expropriation of property by making appropriate, the transfer of an area can offer the service, even if indirectly stated.

- However, instead of this meaning as well, in case of the fields owned by the 3rd parties can also be separated for the transfer service by means of contract can be made in return for a share of the construction.

- This interpretation that is the purchase has the meaning given to that provision, according to the Expropriation Act, this "agreement with the expropriation" is.

- In this case, the conservation is a public service; this public service is not only given the protected areas 
expropriated. Also people's settlement rights are ensured for living in a healthy urban environment. That is meaning an important task for the state.

- The state defines the open spaces for zoning with the development plans. So that by transferring these rights, to the transfer area separated, in the fact that the problems can be solved, is adopted.

\subsubsection{The 2nd Areas for the Property Owner without the Land Shares}

In the Condominium Act, before the start of construction, the building contractor and property owner, for switching to the independent property right in the future, reciprocal easement agreement in the first stage can established until the independent departments becomes suitable for use in its own right.

In this organization, reciprocal easement agreement for 50-year period can be established in the following conditions: According to the principles of joint ownership in each of the independent sections how being allocated in the rate of land share value. In here, the public owners' land and private owners' structure are separated in form of individual owners to be made an arrangement of property left until a legal regulation, a temporary agreement until 50 -year period can be established, is estimated.

In the future, "the property owner without the land shares" in mind when the construction is completed.

- When the Condominium Act re-adjusted, these rights must be kept as established with the reciprocal easement right agreement.

- Even if, the land of public ownership and in form of private/corporate eligible individuals at the top of the building property, all kinds of savings in legal entities can be authorized for the independent on the rights.

- To this regulation, the public ownership of land, which is in the area established rights in these transfer lands should not be sold or transferred in any reasons. Otherwise, the preemption rights would be arising with "the property owner without the land shares" for its owners.

- All these sanctions and rights can be recognized in the reciprocal easement right agreement.

This arrangement is made for protecting to transfer of the property and the development rights in the immovable cultural and natural assets. These easement that is "the property owner without the land shares", the new legal regulation on the conclusion of equality, justice, housing, to resolve on the basis of respect for the rights of life, can be saved in establishing easement conditions.

Those relationships between the parts are the most important: shares"

1. Part: "the property owner without the land

2. Part: "the property owner with the land shares"

If these parts are present in the same field, the use of public places, preservation, and maintenance-repair with the related provisions for using, in what way the relationship can be maintained in the contract agreement.

The settlements rights transfers for "the property owner with the land shares" should be done in a separate island or parcel albeit in the same area. As required about them, a separate transfer incorporated entity is established in legally, and the construction can be continued in this way.
3.3. The Devoted Space for Transfer in the Development Plan Theory

The lacking of the legal-administrative framework and also many problems are in below so this approach is the mostly important with these reasons.

\subsubsection{The Lacking of Legal \& Administrative} Framework and the Regulations

That example as a first serious regulation is showed by some reasons for securitization, which is used in our sub-model (BTM-SSM) very carefully [19]. Firstly, evaluation and securing lost rights in the real property had been adapted for giving with a site certificate by the inclusion of the new article into the law scheme of 29th of August, 2001. (Law No. 4706, No. 6 article)

Two years later, this first Law (Law No. 4706) was amended by another Law (Law No. 4916) of the 3rd of July, 2003. The "Approved" terms had been settled with the coming into force of the Conservation Development Plan to implement this new provision by municipal election, minister, related governing after board positive decision.

Another example is about complex authorization that needs coordination, in the law.

The authorities and local government bodies are authorized for transfers under section regulated by the Law. (Law No. 2863, amended as Law No. 5226/14.7.2004, No.17 article, cth paragraph). It contradicts with law reason in the following:

"Transfer is not only for single-transaction owners in a -building land, but a contemporary tool which shall use principles and criteria actually providing a balance between the public interest and individual and corporate ownership."

In epitome, transfer shouldn't use by mistake like as the confiscation in the expropriation in the form of a unilateral public power.

The Expropriation Law, (Law No. 2942/4.11.1983 amended as Law No. 4650/24.04.2001, No. 1/2, 5/c and also 8, 26 articles/sub-sections).

The expropriation heavily criticized in society. Its name begins with the public, but the different priorities are in the following: The expropriation for the benefit of natural persons or the purchase or exchange procedures. The principles in the transfer sub-model (BTM-TSM), which have been proposed by last dissertation study, have also these reasons [19].

In the last years, while many urban transformation projects have been managed, the right of property, living, housing and cultural rights have been practically insulted so that thousands of people have been displaced, and new a homeless and unemployed mass of people has emerged.

For example, Sulukule is a historic neighborhood adjacent to the old city center. This application implements a political segregation, which is also supported by urban entrepreneurialism as a part of the local municipality's urban renewal program.

Then, the Municipality Law (Law No. 5393, No. 53 article) was approved an article title that is named by "Emergency planning" to renewal in earthquake areas.

By another law (17/6/2010 Law No. 5998) has amended the Municipality Law (5393, Article No. 73) 
again. It is about urban regeneration and development applications, which are more flexible than before.

The most common means of implementation of development plans, the expropriation has been applied for a long time. But it is the only bias in the lack of participation, the placement, housing, housing rights objectives has prevent the success of implementation.

The development rights for the development plans are not clearly defined with the purpose, definition, scope, content in the laws. Besides the explanations are also not enough.

In addition, urban planning and zoning powers given to different institutions posed problems as follows:

- Chaotic growth, uneven development, the plan also application schemes, public releases, etc.

- The deterioration of development integrity in the national and regional levels,

- Lastly, the urban development leads to the emergence of the privilege.

There is not enough relation the planning processes between development plans by the country's plans. The problems created by a privileged ride go this way and arise at the country level and to increase further as a result of heavy construction. Shortly, for the correction will be created in the increasingly impossible conditions.

Some of the problems as follow;

- The regulatory gaps, the lack of integrity in the principle,

- Although the citizens of settlement, shelter and housing rights in the Constitution is given the task to observe for the state,

- The gaps in the legal regulations and the problems arising, due to incompetence, urban environments lead to the creation of slums and illegal construction satellites.

Consequently, Transfer of Limited Rights Model (TLRM) approach has been considered with the framework of Basic Transfer Model (BTM) as an alternative tool instead of expropriation.

\subsection{The Transfer Applied with the 2nd Areas}

TLRM approach deeply riched by this study can be considered as a complicated solution, because of its comprehensive framework which is covered this new subtitles such as Transfer Incorporated Entity (TIE). Firstly this explanation should remember: TLRM is also based on the framework of Basic Transfer Model (BTM \& its Transfer sub-model) as an alternative tool instead of just expropriation [13].

3.4.1. A New Transfer Approach: Transfer Incorporated Entity (TIE)

The TIE is a corporation that is proposed its structure designed by named as Transfer Incorporated Entity. The TIEs can be responsible for taking the active roles in Transfer of Development Rights (TDR) programs, because there are many different ways to realize the process of necessary compensation in the conservation applications easily. For example: There are some meetings in which owners must participate in a TDR program. Some of these meetings can be a public education or a program management conciliation.

The local government bodies are joint with the owners of the areas (1st, 2nd) is generally in all processes. At the same time, this situation is necessary to manage all the important process from beginning end under local conditions by the way of establishing with the reciprocal easement rights.

The local governments will establish a simple partnership (Transfer Incorporated Entity-TIE) with the private owners and the leaders (as most have a share) will carry out this scheme. In this respect, TIE supplies a suitable and efficient cooperation approach as follows:

- The transfer requests are determined for all private owners' immovable assets.

- The property owners after the announcements about general information and the notifications, they would be able to invest to the Transfer Incorporated Entity (TIE) with their certificates. The public and private property owners put their assets as a share in the TIE.

- The transfer incorporated entity (TIE) which is established to enable the transfer of the security can realized all necessities.

- At the same time, they have duties, authority and responsibility granted to them in the TIE according to the law. (Law No. 2863/21.7.1983, No. 17 article, amended as Law No. 3386/17.6.1987 and No. 17 article, cth paragraph, amended as Law No. 5226/14.7.2004)

- A little while later, a conciliation period can be started by actors who have completed this process in every respect such as for a TIE.

Now repeat shortly the entire process can be reviewed with taking into account of TIE as a facilitator:

- Firstly, the conservation development plan for the immovable cultural and natural heritage should be done.

- Thus, the prohibition of building as certain (full, final, absolute) and partial must be determined.

- Then, the rights to be transferred are evaluated.

- The immovable property who continues to occur is defined with it.

- When the limited rights, decisions will be taken regarding the transfer of 2 nd areas, these will create the basic steps in the model.

To do this:

- If the real estate restricted certainly with all equipment and add-ons during in absolute prohibition of building, it becomes in the property of the government and its sales can't be. All transactions are made accordingly; its evaluation is the first priority.

- But the restriction of building can be partly. In this case, the ownership of the property owner's will continue in the land and buildings. Accordingly their evaluation and transfer operations should be made "the property owner with the land shares". Thereby the limited building rights will have waited these operations. In here, the public owners' land and private owners' structure are separated in form of individual owners with an arrangement of property.

- Also unused restricted rights after the evaluation case must be converted to cash. The securitization processes can be also made, if necessary. The cash value of money, the right holder will be given to his request way. All the transfer operations of the limited rights should be facilitated by two different land types particularly in above.

However, even within the same area, the different islands and parcels can be separated for the different types of transfer depend on the restrictions in above. Therefore, the different TIEs can be also 
established with separately, if necessary for different transfers.

For these reasons, this model is an application instrument in all of the development plans instead of expropriations. Thus, the parties can take for task, responsibility with authority. In conclusion, a system balanced between the private limited property and development rights with their benefits and the public interest can be implemented by this model. The restricted rights transfer to the reserved areas with plans and this solution will create an effective approach to every problem.

These purposes, separate the expropriation of
and the citizens
construction, residential, housing and housing right sand also to meet the requirements, regulations must be kept in the first place. Thus, the provisions for development plans to be issued with the transfer of rights can be restricted applications.

\section{CONCLUSION}

The building-development rights are homogeneous to the immovable property rights in our country. Because of this situation, in principle, an independent property right should be considered as legal norms [22].

Although the right of building has been included into the legislation of conservation through the Law (No. 2863 ) in 2004, these rights must be demanded insistently by the community informed on this issue. However, the architects, town planners, engineers and lawyers also are expected to be leading to this demand.

The immovable property is not a single right by itself. It also covers the rights of building-development. Besides, within the scope of this right there are also the rights of city, the environment and the living.

In a sense, all of them must be also taken into consideration. However, these potential rights must also be demanded by owners. Nevertheless, it has been late to the creation of this awareness in the public [21].

The assessments in the dealings of real estate between public and private should need to be done by committees at the national level with the same principles, criteria and methods.

Besides, these processes with all the qualities and quantities should be realized by keeping placement, housing, housing, environmental issues and rights of life in mind and then, equivalents of these must be reimbursed to owners by governments.

In addition, the following topics should be the most priority of subject: [22]

- Cultural, historical, urban, archaeological and natural site assets;

- Coasts, forests, pastures, meadows, grasslands, scrubs, and national parks;

- For the protection of catchment's basins such as dams, under ground and surface water basins, swamps;

- With the precautions taken against the possible natural disasters, forest fires, floods, avalanche blasts, before earthquakes and then,

- For the benefit of public service and order in the urban and the regional-level conservations, renewals and transformation projects, [23] are the most important issues.

In the means of implementation of development plans, together with the expropriation and changes, the rights of transfer in a contemporary approach, should be based on the realization of the principles of a social state of law [19].

In all over the world, new approaches have been needed to integrate into the theories of planning during recent years. One of these is allocation of the areas of the limited real rights reserves. Even though overdue in this subject, the joining urgent seems mandatory. Because this has been ignored so far, immediate actions on this issue seem necessary.

\section{REFERENCES}

1. 18.10.1982/2709 dated/numbered T.R. The Constitution Article No: 43, 44, 45, 46, 56, 63, 268 ve 169.

2. 23.7.1983/2863 dated/numbered the Law for Conservation of Culture \& Natural Assets (LCCNA), 11.8.1983/2872 numbered the Environmental Law, 17.4.1990/3621 numbered the Coast Law, 31.8.1956/6831 numbered the Forest law, 28.2.1998/4342 numbered the Pastures Law, 23.12.1960/167 dated/numbered the Ground water Law.

3. 3.5.1985/3194 dated/numbered the Zoning Law Article No 2, 8.

4. 3.5.1985/3194 dated/numbered the Zoning Law Article No 1, 3.

5. 23.7.1983/2863 dated/numbered the LCCNA, 17.6.87/3386 dated and 5226 numbered Act amended the Article 15and sub-sections amended .

6. Eryoldaş, A. ve İnankul, Ş. (1991) Planlı Dönemde İmar Planlarının Mülkiyet Üzerine Etkileri, Türkiye'de 15.Dünya Şehircilik Günü.

7. Görgülü, Z. (2006) “Özçeli, B. ile söyleşisi”, Milliyet, 10.9.2006.

8. Kocalar, A.C. (2009) "Transfer of Property and Development Rights in Immovable Property on which the Conservation Development Plan has been Implemented," p.257, 289-315, 316-325, 330-355, 409-412, 413-418, 419, 420, Unpublished Doctoral Dissertation, MSGSÜ, INS, İstanbul.

9. Turkish Civil Law (TCL), 1.1.2002/4721 dated/numbered, it covers that the Book 4, the Chapter 1, and the Section 2: The immovable property, the Chapter 3: The deed and the possession subjects.

10. TCL, Article 7 "Official records and notes are an evidence of the accuracy of the cases."

11. TCL, Articles 704, 998 .

12. TCL, Articles 704-761.

13. Kocalar, A. C. (2010-b) "Transfer of Limited Property and Development Rights in Immovable on Which Conservation Development Plan Has Been Implemented," 12th International New Housing Reserachers' (NHR 2010) Colloquium. İTÜ İstanbul 2-3 July 2010.

14. Ünal, E. v.d. (1998) "Zoning Glossary", TODAİE.

15. Keleş, R. (1993) Kent ve Siyaset Üzerine Yazılar, IULA-EMME, İstanbul. 
16. Ünal, E. (1998)

17. 23.7.1983/2863 dated/numbered the LCCNA, 17.6.1987 dated and 3386 numbered Act amended the Article 17. 2th sentence has been canceled by the Supreme Court decision that is the principle Date/No:1987/21, the decision Date/No:1988/25)

18. 23.7.1983/2863 numbered the LCCNA, 14.7.2004 dated and 5226 numbered Act amended the Article 17/c-18.paragraf.

19. Kocalar, A.C. (2010-c) "Nation-wide Implementation of Transfer by Local Authorities under the Conservation Development Plan by Ministry of Culture and Tourism in Turkey", Urban Transformation: Controversies, Contrasts and Challenges; 14th International Planning History Society (IPHS) Conference. İTÜ İstanbul 12-15 July, 2010.

20. 23.7.1983/2863 dated/numbered the LCCNA, 14.7.2004 dated and 5226 numbered Act amended the Article $17 / \mathrm{c}$.

21. Kocalar, A. C. (2010-a) "Evaluated Transfer of Limited Property and Development Rights in Immovable on which the Conservation Development Plan Has Been Implemented," Tasarım ve Kuram Dergisi. MSGSÜ İstanbul. Cilt 6, Say1 9-10 (2010). s. 71-81.

22. Kocalar A.C. (2011) "Transferring of Limited Rights Model (TLRM) with the highest priority in the Theory of Development Plans." $9^{\text {th }}$ Meeting of AESOP Thematic Group on "Complexity and Planning", "Self-Organizing and Spatial Planning". YTÜ İstanbul 29-30 April 2011.

23. Kocalar A.C. (2010-d) "Evaluation of Environment and Living Rights of Ecological Systems while Transferring of Limited Property and Development Rights in Immovables", Greenage $1^{\text {th }}$ International Symposium. İstanbul Mimar Sinan Fine Arts University Faculty of Architecture 6-8 December 2010. Proceedings. s. 258-269.

\section{Laws}

For the "Coast Law 17.4.1990/3621" dated/numbered.

For the "Condominium Law 23.6.1965/634" dated/numbered.

For the "Environmental Law 11.8.1983/2872" dated/numbered.

For the "Expropriation Law, No. 2942", see: "2942 say1l Kamulaştırma Kanunu”, Official Gazette, 4.11.1983, No. 1 article, $2^{\text {nd }}$ paragraphs, No. 5 article, $c^{\text {th }}$ paragraphs, and No. 6 article, $h^{\text {th }}$ paragraphs.

For the "Expropriation Changing Some Clauses and Adding Some New Clauses to Mentioned Law, No.
4650", see: "2942 sayılı Kamulaştırma Kanununda Bazı Maddelerini Değiştiren ve $\mathrm{Bu}$ Kanuna Bazı Maddeler Eklenmesi Hakkında Kanun", Official Gazette, 24.4.2001, see: "Law No: 2942, No. 1 article, $2^{\text {nd }}$ paragraphs, No. 5 article, $c^{\text {th }}$ paragraphs and No. 8 and 26 articles".

For the "Evaluation Law for Immovables belong to National Tresury, No. 4706", Official Gazette, 29.8.2001, see: "No. 6 article, $2^{\text {nd }}$ sub-section".

For the "Evaluation for Immovables belong to National Tresury Changing and Adding Some Clauses to Mentioned Law, No. 4916", see: "Hazineye Ait Taşınmazlar Malların Değerlendirilmesi ve KDV Kanunda Değişiklik Yapılması Hakkında Kanun" Official Gazette, 3.7.2003, see: "Law No: 4706, No. 6 article, $2^{\text {nd }}$ sub-section".

For the "Forest Law 31.8.1956/6831" dated/numbered.

For the "Groundwater Law 23.12.1960/167" dated/numbered.

For the "Law for Conservation of Culture \& Natural Assets (LCCNA), Law No. 2863", see: "2863 say1l Kültür ve Tabiat Varlıklarını Koruma Kanunu (KTVKK)" Official Gazette, 21.7.1983, see: "No. 15 article, $\mathrm{a}^{\text {th }}$ sub-section, and $\mathrm{c}^{\text {th }}, \mathrm{d}^{\text {th }}, \mathrm{e}^{\text {th }}$ sub-sections and No. 17 article".

(Official Gazette, see: 14.7.2004 dated and 5226 numbered Act amended the Article 17/c, 17/c18.paragraf.)

(Official Gazette, see: 17.6.1987 dated and 3386 numbered the Act amended the Article 17.2.sentence has been canceled by the Supreme Court decision that is the principle Date/No:1987/21, the decision Date/No:1988/25) (see: the Article 17/c).

For the "Municipality Law 13.07.2005/5393" dated/numbered Act." No. 53, 73 article.

(Official Gazette, see: 17/6/2010 dated and 5998 numbered Act has amended the Municipality Law (5393, Article No. 73))

For the "Pastures Law 28.2.1998/4342" dated/numbered.

For the "Turkish Civil Law (TCL), 1.1.2002/4721" dated/numbered, the Articles 704, 998, 704-761.

(It covers that the Book 4, the Chapter 1, the Section 2: The immovables property, the Chapter 3:The deed and the possession subjects, the Article 7 "Official records and notes are an evidence of the accuracy of the cases.")

For the "T.R. Constitution 18.10.1982/2709" dated/numbered the Article No: 43, 44, 45, 46, 56, 63, 268, 166 and 169.

For the "Zoning Law, 3.5.1985/3194" dated/numbered, the Article No 1, 2, 3, 8 . 